UDK 630*92:519.237.8(497.6)

\title{
A TYPOLOGY OF PRIVATE FOREST OWNERS IN BOSNIA - HERZEGOVINA BASED ON DIFFERENT CLUSTERING METHODS
}

Tipologija privatnih šumoposjednika u Bosni i Hercegovini bazirana na različitim metodama združivanja

\author{
Azra Čabaravdić ${ }^{1}$, Mersudin Avdibegović ${ }^{1}$, Nijaz Kadrić ${ }^{1}$, Bruno Marić ${ }^{1}$, \\ Sabina Delić ${ }^{1}$, Špela Pezdevšek Malovrh ${ }^{2}$
}

\begin{abstract}
According to FAO, the total forest area in Bosnia-Herzegovina amounts 2.709.769 ha or $53,4 \%$ of overall state territory. While the total area of private forests is 523.437 ha, private forest ownership is characterized by huge number of small-scale and fragmented individual estates. The aim of this research is to examine how the groups of private forest owners can be created with different clustering methods, regarding different criteria. The data presented in this paper are obtained from PRIFORT project (Research into the Organizations of Private Forest Owners Associations in the Western Balkan Region). Results show that private forest owners in BosniaHerzegovina can be grouped in three clusters by using different clustering methods, based on criteria defined in advance. Significant differences in willingness of private forest owners (PFO) to join to their interest associations are noticed for identified clusters. From forest policy aspect, the clusters gathering homogenous groups of private forest owners should be treated by different policy instruments (regulatory, economical or informational) in order to ensure better contribution of private forests to overall economical, ecological and social outcomes expected from forests as the most important natural resources in Bosnia-Herzegovina.
\end{abstract}

Key words: Bosnia-Herzegovina, forest policy, private forests, private forest owners, interests associations of private forest owners, clustering methods.

\footnotetext{
${ }^{1}$ Faculty of Forestry, University of Sarajevo

${ }^{2}$ Department of Forestry, Biotechnical Faculty, University of Ljubljana
} 


\section{INTRODUCTION - Uvod}

According to FAO reports total forest area in Bosnia-Herzegovina (hereinafter: B-H) is 2.709 .769 ha or $53,4 \%$ of the state. About 523.437 ha $(19,3 \%)$ of total forest area belong to private owners (FAO, 2006). This implies a need to investigate and understand different issues related to private forest ownership within the efforts to create consistent national forest policy and define sound guidelines for further development of the forest sector. Specific historical, economical, political and social circumstances in B-H resulted in relatively modest amount of scientific research related to private forest ownership. The most comprehensive study on private forest owners in the Western Balkans and their readiness to create interest associations has been completed within PRIFORT project. In papers, where the results of this study have been published, some findings on private forest owners' population, the state of private forests as well as owners' attitude towards different management aspects have been particularly elaborated (GLÜCK ET AL., 2010; PETROVIĆ \& ČABARAVDIĆ, 2010). The total number of private forest owners in B-H has been estimated to roughly 500.000 with small average size of individual forest property and mostly fragmented in several parcels. Furthermore, the identified social-demographical profile of typical private forest owner is characterized by middle age (mean age: 52 years), residence in rural areas, with lower level of education and prevailing male gender. A half of private forest owners are not employed and they have low economical effects from their forests (MARIĆ, 2010). Relatively high diversity of forest property size, specific species composition, poor management system as well as pronounced need for different assistance from public forest administration pointed out the need for organization of private forest owners into Private Forest Owners Associations (hereinafter: PFOAs). The different policy options for private forest owners in the Western Balkans as well as necessary preconditions for the formation of PFOAs are explained in detail only recently (AVDIBEgović ET AL., 2010A; Avdibegović ET AL., 2010B; Avdibegović ET AL., 2010c).

Private forest owners differ regarding their properties, attitudes and objectives, so usually preliminary research is related to examination of their typology (distinctive subgroups or clusters of private forest owners). Different criteria are examined and used targeting forest owners that are clustered regarding to their own characteristics, objectives or planned actions. Related clustering methods are usually presented in different textbooks on marketing or quantitative methods in socioeconomic research (BALNAVES, 2001; CRESWELL, 2002; MALHOTRA, 2007). A number of private forest owners' typologies have 
been proposed by researchers. These typologies are mainly defined according to differences with regard to ownership objectives (INGEMARSON ET AL., 2006; MAJUMdAR ET AL., 2008; NovaIS ET AL., 2010; URQUHART ET AL., 2011). A review reveals that typologies typically divide private forest owners into 5 main groups: (1) the economists, (2) the multi-objectivists, (3) the self employed, (4) the recreationists and (5) the passive/resigning (BOON ET AL., 2004).

The data referring to B-H obtained through PRIFORT project, become a kind of cornerstone for further, more detailed research of private owners and private forest ownership. It was clearly noticed that PRIFORT data should be further explored by applying advanced statistical methods. This paper deals with application of different clustering methods in order to identify the specific groups of private forest owners with different needs related to management of their forests. The findings might be useful for both, private forest owners who want to manage their forests in a way to obtain better effects of their property, and the key forest policy actors who are responsible for developing such a policy framework that would make sustainable forest management possible, regardless the type of forest ownership.

\section{MATERIAL AND METHODS - Materijal i metod}

The data on private forest owners as well as specific attributes of their forests, collected in PRIFORT project, were used in this paper. The data were collected by using tailor-made questionnaire applied on sample of 350 private forest owners in B-H from nine municipalities (Berkovići, Goražde, Kneževo, Krupa na Uni, Ljubinje, Milići, Sapna, Široki Brijeg, Stari Grad). The questions used to form the basis for making private forest owners' typology covered the following aspects: (Q1) interest for PFOAs which would support private forest owners in forests management, (Q2) interest for PFOAs which would lobby for private forest owners' interests (Q3) forest property data (acreage, type of forest, species composition), (Q4) purchase and sale of forest property, (Q5) forest property fragmentation and (Q6) willingness for cooperation with other forest owners in different activities. Responses were measured on five-level ordinal Likert scale (1-5), absolute metrical (numerical continuous and discrete variables) and nominal scale (categorical variables). Likert scale data are considered as continuous in calculations. The data are processed using statistical program SPSS 15.00.

The different clustering methods have been applied as follows: poststratification, two-step cluster, k-means cluster and hierarchical cluster 
analysis. Post-stratification can be assigned as clustering or clustering method based on numerical continuous variable. Using approximate Dalenius-Hodges solution variable distribution is transformed by using square function, and then cumulative distribution of transformed values is created and divided in number of predefined intervals equally (PETROVIĆ, 2005, 2007). Two-step clustering considers categorical and continuous variables in order to create natural grouping of cases. It is based on a likelihood distance measure assuming variables independence. Also each categorical variable is assumed to have a multinomial distribution and each continuous to have normal (Gaussian) distribution. The k-means clustering considers continuous variables only creating relatively homogeneous groups of cases based on Euclidian distance and selected characteristics with predefined number of clusters. Hierarchical clustering deals with cases instead of variables creating clusters based on distance or similarity measures. Agglomerative hierarchical methods consider the most similar cases as the first group, and then initial groups are merged according to their similarities. Closer groups are then fused into a single cluster. The results may be displayed in the form of a two-dimensional diagram known as a dendrogram. Clustering is performed using particulare linkage methods (single, complete, average linkage or Wards method) and distances. Here is used single linkage based on squared Euclidian distance (JOHANSON\&WICHERN, 2002).

Focused differences between methods are based on variably types (continuous, categorical, binary and count) creating particular approach for clustering in this research (KADRIĆ, 2009). Besides, the attitudes of private forest owners towards PFOAs for management and lobbying (depending on clusters identified by using different methods) are explored in this paper. Significant differences between clusters are examined using non-parametrical MannWhitney U test (SOKAL\&ROHLF, 1995).

\section{RESULTS AND DISCUSSION - Rezultati i diskusija}

Apart from main characteristics of examined population, it is also necessary to identify distinctive subgroups based on different criteria. Policy and decision makers are interested in size of these subgroups (\% distribution) but also in their main characteristics, similarities and differences. Some specifics of their forest property as well as their attitudes are obtained by analyzing of their responds on 6 selected questions (see Appendix 1.). Descriptive statistics of continuous, categorical and Likert scale variables are 
presented in Table 1 (mean, mode, standard deviation, minimum and maximum), Table 2 (mode) and Table 3 (mean, mode, standard deviation) respectively.

Table 1. Private forest owners in B-H - Continuous variables statistics

Tabela 1. Privatni šumposjednici u $B-H$ - Statistike kontinuiranih varijabli

\begin{tabular}{|c|c|c|c|c|c|}
\hline Question & Mean & Mode & Std. deviation & Min & Max \\
\hline Q3_a (Acreage) & 3,1 & 0,3 & 10,7 & 0 & 150 \\
\hline Q4_a (Purchase) & 0,3 & 0 & 4,4 & 0 & 80 \\
\hline Q4_b (Sale) & 0,01 & 0 & 0,1 & 0 & 1 \\
\hline Q5_3 (Number of parcels) & 2,2 & 2 & 1,9 & 0 & 12 \\
\hline Q5_4 (Average size of parcels) & 1,2 & 0,2 & 3,9 & 0 & 40 \\
\hline
\end{tabular}

Table 2. Private forest owners in B-H - Categorical variables statistics

Tabela 2. Privatni šumposjednici u B-H - Statistike kategorijskih varijabli

\begin{tabular}{|l|c|}
\hline \multicolumn{1}{|c|}{ Question } & Mode \\
\hline Q3_b (Type of forest) & 3 \\
\hline Q3_c (Species composition) & 2 \\
\hline Q4_a (Purchase within last 10 years) & 1 \\
\hline Q4_b (Sale within last 10 years) & 1 \\
\hline Q5_1 (Forest consolidated or fragmented) & 2 \\
\hline
\end{tabular}

Table 3. Private forest owners in B-H - Likert scale variables statistics

Tabela 3. Privatni šumposjednici u B-H - Statistike varijabli Likertove skale

\begin{tabular}{|l|c|c|c|}
\hline \multicolumn{1}{|c|}{ Question } & Mean & Mode & Std. deviation \\
\hline Q1 (Interest for PFOAs for management) & 2,2 & 2 & 1,2 \\
\hline Q2 (Interest for PFOAs for lobbying) & 2,2 & 2 & 1,2 \\
\hline $\begin{array}{c}\text { Q6_a (Sharing harvesting equipment) } \\
\text { (Zajedničko korištenje opreme) }\end{array}$ & 3,4 & 4 & 1,3 \\
\hline Q6_b (Sharing management plans costs) & 3,5 & 4 & 1,2 \\
\hline Q6_c (Selling forest products) & 3,7 & 5 & 1,3 \\
\hline Q6_d (Common forest training) & 3,1 & 2 & 1,3 \\
\hline Q6_e (Forest road construction and maintenance) & 2,0 & 1 & 1,2 \\
\hline
\end{tabular}

As it was already mentioned, the population can be clustered in different ways, depending on particular criteria. The results of different cluster methods examined here are shown as follows. 
Post-stratification was based on forest property size (ha). Data of forest property size showed enormous variability and non-existence of normality. The Lorence curve was constructed in order to examine population distribution. The inequality of property size distribution was confirmed, extreme values identified and excluded. Further analysis considered remained $98 \%$ data which were less than 20 ha. Even $80 \%$ of forest properties were less then 3,0 ha pointed out dominance of small scale properties. Using HodgesDalenius rule for Neyman's optimal allocation three strata (clusters) are identified:

- Cluster of forest owners with very small property size (less then 0,70 ha) (51\%),

- Cluster of forest owners with small property size $(0,71-3,00 \mathrm{ha})$ $(35 \%)$,

- Cluster of forest owners with medium property size (larger then 3,00 ha) (14\%).

Comparing to the owners with smaller properties, the third cluster (forest owners with property size larger then 3,0 ha) expressed the higher interest for PFOAs which would support private forest owners in forests management. The interests for PFOAs which would lobby for private forest owners' interests were consisted. The differences of interests were not significant so it could be concluded that there is no differentiation in interest for PFOAs for forest owners with different property size.

Two-step clustering is clustering method where categorical and continuous variables could be compiled. In this research three questions related to quantitative (property size in ha, timber use in $\mathrm{m}^{3} /$ year and number of parcels) and qualitative (species composition, type of forests) variables were used. Two-step clustering resulted in three clusters:

- Forest owner cluster with larger property size (average 3,03 ha), the highest wood use and broadleaved dominated coppice forest $(51 \%)$,

- Forest owner cluster with small property size (average $0,92 \mathrm{ha}$ ), the lowest wood use and conifers dominated high forest (17\%) and

- Forest owner cluster with very small property size, the moderate wood use and mixed forest considering composition and origin $(32 \%)$.

Statistical analysis of obtained clusters showed no differences in interest for PFOAs between clusters based on examined criteria.

The k-means clustering was based on forest owner's willingness for cooperation in different forest management activities. Here were determined three means $(k=3)$ aiming to identify clusters with three level of willingness 
for cooperation (low, medium, high). A result of the 3 means clustering is presented in Table 4.

Table 4. Private forest owners' clusters based on their willingness for cooperation

Tabela 4. Karakteristike klastera privatnih šumoposjednika prema interesu za saradnju

\begin{tabular}{|c|c|c|c|}
\hline \multirow{2}{*}{ Common activity } & \multicolumn{3}{|c|}{ Cluster } \\
\cline { 2 - 4 } & 1 & 2 & 3 \\
\hline Sharing harvesting equipment & 2 & 3 & 5 \\
\hline Sharing costs for making forest management plans & 2 & 4 & 4 \\
\hline Selling forest products & 2 & 4 & 5 \\
\hline Forest training & 2 & 3 & 4 \\
\hline Forest road construction and maintenance & 1 & 1 & 3 \\
\hline
\end{tabular}

The following three clusters are identified with the following characteristics:

- Forest owners with high interest for cooperation in all activities $(34 \%)$,

- Forest owners with high interest for cooperation in forest road construction and maintenance only (37\%) and

- Forest owners without interest for cooperation (29\%).

Interest for PFOAs which would support private forest owners in forests management and lobby for private forest owners' interests is consistent with willingness for cooperation: the first cluster expresses high need for PFOAs, the second cluster moderate interest while the third cluster did not express a need for PFOAs. Similar results were obtained in whole Western Balkan region (GLÜCK ET AL., 2010 IBID).

Hierarchical clustering performed in this research was based on interest for PFOAs which would support private forest owners in forests management and lobby for private forest owners' interests (Q1 and Q2 in appendix) and cooperation (common mechanization use, sharing expenses for forest management plans, common timber trade, education and sharing costs for forest road construction and maintenance). Sample municipalities were assigned as cases and hierarchical clustering performed (Feature 1). 
Feature 1. Dendrogram (means connection)

Slika 1. Dendrogram (povezivanje prosjeka)

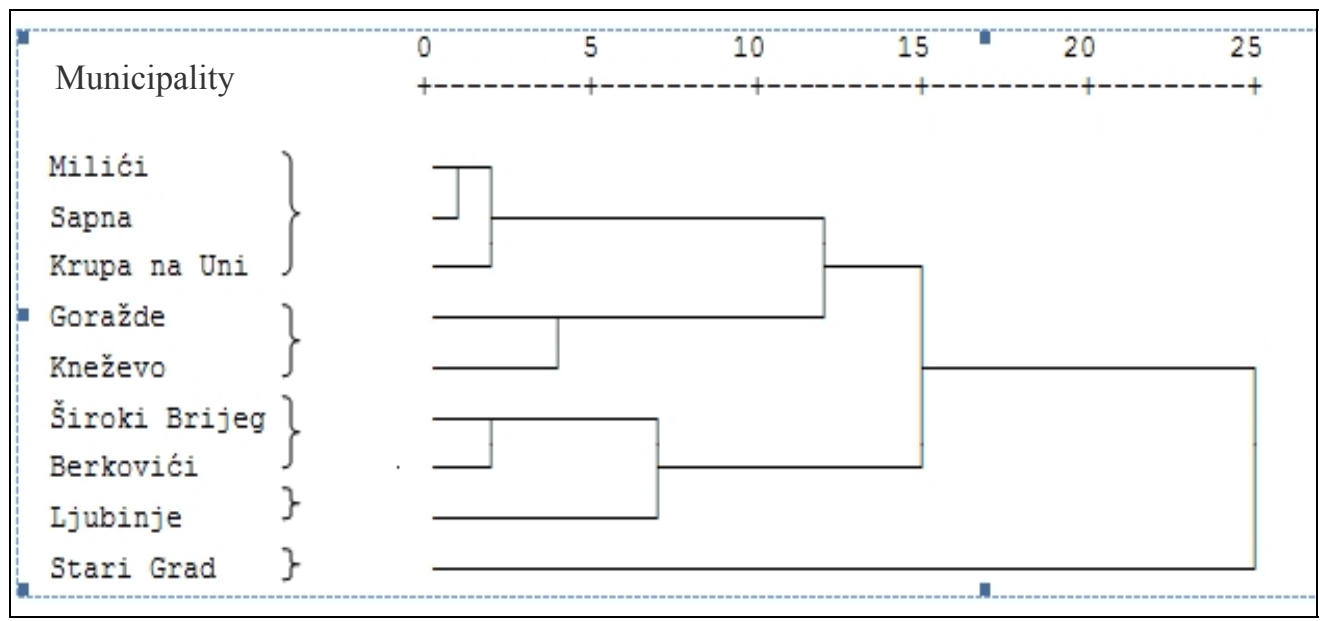

The main characteristics of identified clusters were determined by using means (Table $5)$.

Table 5. Distances and question's means using in hierarchical clustering of municipalities Tabela 5. Udaljenosti i prosjeci pitanja korištenih u hijerahijskom združivanju općina

\begin{tabular}{|c|c|c|c|c|c|c|c|c|}
\hline Distance & Municipalities & Q1 & Q2 & Q6_a & Q6_b & Q6_c & Q6_d & Q6_e \\
\hline 1 & Milići & 2,7 & 2,8 & 4,1 & 3,8 & 4,1 & 3,3 & 2,1 \\
\hline 2 & Sapna & 2,4 & 2,5 & 4,0 & 3,6 & 3,7 & 3,3 & 2,1 \\
\hline 3 & Krupa na Uni & 2,4 & 2,5 & 3,5 & 3,5 & 3,2 & 3,1 & 2,1 \\
\hline 4 & Goražde & 1,7 & 1,7 & 2,5 & 2,5 & 2,7 & 2,5 & 1,4 \\
\hline 5 & Kneževo & 1,6 & 1,7 & 3,0 & 3,4 & 3,6 & 2,8 & 1,7 \\
\hline 6 & Šroki Brijeg & 1,9 & 1,8 & 2,5 & 5,0 & 5,0 & 3,5 & 2,6 \\
\hline 7 & Berkovići & 2,0 & 2,2 & 2,8 & 4,6 & 4,8 & 3,8 & 2,0 \\
\hline 8 & Ljubinje & 1,7 & 1,6 & 3,4 & 4,2 & 3,9 & 4,4 & 1,9 \\
\hline 9 & Stari Grad & 3,8 & 3,9 & 3,0 & 3,4 & 4,0 & 3,7 & 3,3 \\
\hline
\end{tabular}

1 Do you miss an interest association of private forest owners which supports you in managing your forest properly, for example, if you have any questions concerning silviculture, harvesting or timber market?

2 Do you miss an interest association of private forest owners in your region which represents the interests of all private forest owners by lobbying political parties, civil servants in ministries or government so that the social and economic situation of private forest owners will be improved?

3 Are you ready to cooperate with other forest owners in the following activities: (a) Sharing harvesting equipment; b) Sharing costs for making forest management plans; c) Selling forest products; d) Forest training; e) Forest road construction and maintenance; f) Others. 
The following municipality clusters were identified:

1. Milići, Sapna and Krupa na Uni with moderate interest for PFOAs and willingness for cooperation in forest road construction and maintenance,

2. Goražde and Kneževo with high interest for PFOAs and willingness for cooperation in forest road construction and maintenance and common education. In addition, municipality Goražde express moderate interest for cooperation in mechanization use, sharing expenses for forest management plan and common wood trade;

3. Široki Brijeg and Berkovići with moderate interest for PFOAs and willingness for cooperation in mechanization use and forest road construction and maintenance only; sharing expenses for forest management plan and common timber trade;

4. Ljubinje with high interest for PFOAs and willingness for cooperation in forest road construction and maintenance only;

5. Stari Grad without interest for PFOAs and without willingness for cooperation.

The hierarchical clustering resulted with different attitudes towards PFO associations and common activities on municipality level (Table 6).

Table 6. Private forest owners' differentiation in analyzed municipalities related to their interest for PFOAs and common activities

Tabela 6. Diferenciranje privatnih šumoposjednika u različitim općinama u odnosu na interes za asocijacije i zajedničke aktivnosti

\begin{tabular}{|c|c|c|c|c|}
\hline Municiplities & $\begin{array}{c}\text { Interest for } \\
\text { associations }\end{array}$ & $\begin{array}{c}\text { Common road } \\
\text { construction and } \\
\text { maintenance }\end{array}$ & $\begin{array}{c}\text { Common } \\
\text { education }\end{array}$ & $\begin{array}{c}\text { Common } \\
\text { mechanization } \\
\text { use }\end{array}$ \\
\hline $\begin{array}{c}\text { Milići, Sapna } \\
\text { and } \\
\text { Krupa na Uni }\end{array}$ & Moderate & Moderate & - & - \\
\hline $\begin{array}{c}\text { Goražde } \\
\text { and } \\
\text { Kneževo }\end{array}$ & High & High & Moderate & $\begin{array}{c}\text { Moderate } \\
\text { (Goražde only) }\end{array}$ \\
\hline $\begin{array}{c}\text { Siroki Brijeg } \\
\text { and } \\
\text { Berkovići }\end{array}$ & Moderate & Moderate & - & Moderate \\
\hline Ljubinje & High & High & - & - \\
\hline Stari Grad & - & - & - & - \\
\hline
\end{tabular}




\section{CONCLUSIONS - Zaključci}

Considering results of applied different clustering methods (post-stratification, two-step, k-means and hierarchical clustering) one can conclude that different criteria resulted in different PFO cluster sizes and their characteristics. Property size based stratification resulted with three groups (clusters) identifying boundaries of property sizes $(<0,70$ ha, $0,71-3,0 \mathrm{ha},>3,1 \mathrm{ha})$ pointed out majority of very small size forest properties. On the other hand, post-stratification and two-step clustering resulted in three clusters with different forest property features but without differences in interest for PFO association. The $\mathrm{k}$ - means clustering based on willingness for cooperation generated three clusters with different attitude towards PFOAs. The first cluster expressed support for all common activities, the second cluster expressed interest for cooperation in forest road construction and maintenance only while third cluster did not support common activities et all.

In order to decide on the most appropriate clustering method it is necessary to define in advance such clustering criteria that are tidy related to planed action or initiative. For successful clustering it is much more important to choose adequate criteria rather than to focus on variability of population or applied method. An adequate clustering method could strictly identify target groups for planned action and help in designing the most appropriate policy instrument. Considering limited human, financial and other resources in forest policy in B-H, this could be important advantage. For more complex analysis other statistical methods could be used (multivariate methods as factor analysis, PCA analysis, discriminant analysis and others). These methods could contribute to clarify latent features of research data and support further differentiation or characterization of private forest owners.

\section{REFERENCES - Literatura}

Avdibegović, M., Nonić, D., Posavec, S., Petrović, N., Marić, B., MiliJić, V., Krajter, S., IORAS, F., ABrudan, I.V. (2010a): Policy Options for Private Forest Owners in Western Balkans: A Qualitative Study, Notulae Botanicae Horti Agrobotanici Cluj-Napoca, Vol 38, No 1.

Avdibegović, M., Nonić, D., Bliss, J.C., Mataruga, M., Petrović, N., Milijić, V.,

MARIĆ, B. (2010b): Organization of private forest owners in Serbia and Bosnia-Herzegovina: socio-economical characteristics and political indicators, Proceedings of the IUFRO Conference: Small Scale Forestry in

a Changing World, 3.08 Small Scale Forestry, 6.06.02 Extension, 6.06.01 Technology Transfer, Slovenian Forest Institute, Ljubljana.

Avdibegović, M., Petrović, N., Nonić D., Posavec, S., Marić, B., Vuletić, D. (2010c): Readiness of private Forest Owners in Croatia, Serbia and Bosnia- 
Herzegovina to Cooperate in Forest Roads Construction and Maintenance, Šumarski list, No. 1-2, CXXXIV. Zagreb.

BALnAVES, M. (2001): Introduction to Qualitative Methods: An Investigate Approach. Sage Publication, Bk\&CD Rom edition.

Boon, T.E, MeIlby, H., Thorsen, B.J. (2004): An Empirically Based Typology of Private Forest Owners in Denmark-Improving the Communication between Authorities and Owners. Scand J Forest, Vol 19, No. 4, pp. 45-55.

CREsWeLL, J.W. (2002): Research Design: Qualitative, Quantitative, and Mixed Methods Approaches. SAGE Publication.

FAO (2006): Global Forest Resources Assessment 2005, Main Report. Progress Towards Sustainable Forest Management FAO Forestry paper 147, Rome.

Glück, P., Avdibegović, M., Čabaravdić, A., Nonić, D., Petrović, N., Posavec, S., STOJANOVSKA, M. (2010): The preconditions for the formation of private forest owners' interest associations in the Western Balkan Region. Forest Policy and Economics, Volume 12, Issue 4, April 2010, Pages 250-263.

INGEMARSON, F., LINDHAGEN, A., ERIKSSON, L. (2006): A typology of small-scale private forest owners in Sweden. Scandinavian Journal of Forest Research, Volume 21, Number 3, pp. 249-259(11).

JOHANSON, R.A., WICHERN, D.W. (2002): Applied multivariate statistical analysis. $5^{\text {th }}$ Edition. Pearson Education International. Prentice-Hall, Inc.

KADRIĆ, N. (2009): Klasterizacija vlasnika privatnih šuma u Bosni i Hercegovini različitim klasifikacijskim tehnikama. Završni rad I ciklusa studija. Šmarski fakultet. Univerzitet Sarajevo.

Majumdar, I., Teeter, L., Butler, B. (2008): Characterizing Family Forest Owners: A Cluster Analysis Approach. Forest Science 54(2).

MalhotRA, K. N. (2007): Marketing research an applied orientation, Georgia Institute of technology, New Jersey.

MARIĆ, B. (2010): Odnos privatnih šumoposjednika u Bosni i Hercegovini prema institucijama javne šumarske administracije, Sarajevo.

Montgomery, C. D. (2005): Design of Analysis of Experiments. John Wiley\&Sons, Inc.

Novals, A., Canadas, M. J. (2010): Understanding the management logic of private forest owners: A new approach . Forest Policy and Economics, Volume 12, Issue 3, Pages 173-180.

Petrović, N., Čabaravdić, A. (2010): Outlook for the Formation of Private Forest Owners' Associations in the Western Balkan region. Forest Policy and 
Economics in Support of Good Governance. EFI Proceedings No. 58, 2010, p. 63-74.

PETRović, LJ. (2005): Zbirka rešenih zadataka iz teorije uzoraka i planiranje eksperimenata, Ekonomski fakultet, Beograd.

PETRović, LJ. (2007): Teorija uzoraka i planiranje eksperimenata, Ekonomski fakultet, Beograd.

RAŠIĆ BAKARIĆ, I. (2006): Primjena faktorske i klaster analize u otkrivanju regionalnih nejednakosti, Ekonomski fakultet, Zagreb.

Sokal, R. R., RohlF, F.J. (1995): Biometry. Third edition. W. H. Freeman and company. New York.

URquhart, J., Courtney, P. (2011): Seeing the owner behind the trees: A typology of small-scale private woodland owners in England. Original Forest Policy and Economics, Volume 13, Issue 7, Pages 535-544.

URQUHART, J., COURTNEY, P., SLEE, B. (2011): Private woodland owners' perspectives on multifunctionality in English woodlands. Original Research Article Journal of Rural Studies, In Press, Corrected Proof, Available online 19 September.

\section{SAŽETAK}

Istraživanja provedena u ovom radu su imala za cilj da utvrde kako se različitim klasifikacijskim tehnikama mogu kreirati grupe (klasteri) u odnosu na različite kriterije, te na osnovu kojih kriterija se vlasnici privatnih šuma u Bosni i Hercegovini mogu diferencirati kada je u pitanju njihov interes za udruživanje u asocijacije koje bi im pružala podršku u smislu unapređenja gospodarenja šumama i lobiranja za njihov interes.

U ovom radu su korišteni podaci iz projekta PRIFORT (Research into the Organizations of Private Forest Owners Associations in the Western Balkan Region) a za njihovu obradu je korišten statistički program SPSS 15.00. Poststratifikacijom su ustanovljena 3 karakteristična klastera privatnih šumoposjednika koji se ne diferenciraju prema veličini posjeda kada je u pitanju njihov interes za asocijacije.

Tehnikom dvostepenog združivanja ustanovljena su takođe 3 klastera kada su u pitanju karakteristike posjeda, korištenje drvne mase, tip šume i sastav šumskih vrsta. Pored toga, utvrđeno je da se privatni šumoposjednici ne diferenciraju prema navedenim kriterijima kada je u pitanju interes za asocijacije.

Metodom k - prosjeka identificirana su 3 klastera te je ustanovljeno da se šumoposjednici diferenciraju prema njihovoj spremnosti da sarađuju sa drugim vlasnicima šuma u zajedničkim aktivnostima, kada je u pitanju interes za asocijacije. 
Hijerarhijskim združivanjem ustanovljene su značajne razlike u interesu privatnih šumoposjednika u različitim općinama kada je u pitanju interes za asocijacije i zajedničke aktivnosti. Na osnovu naprijed navedenog, potvrđeno je postojanje razlika između šumoposjednika $u$ različitim općinama u odnosu na interes za asocijacij i zajedničke aktivnosti. 


\section{APPENDIX 1. - Dodatak 1.}

1. Do you miss an interest association of private forest owners which supports you in managing your forest properly, for example, if you have any questions concerning silviculture, harvesting or timber market?

$\square$ Very much (1) $\square$ Much (2) $\square$ Don’t know (3) $\square$ A little bit (4) $\square$ Not at all (5)

2. Do you miss an interest association of private forest owners in your region which represents the interests of all private forest owners by lobbying political parties, civil servants in ministries or government so that the social and economic situation of private forest owners will be improved?

$\square$ Very much (1) $\square$ Much (2) $\square$ Don’t know (3) $\square$ A little bit (4) $\square$ Not at all (5)

3. Please specify the following silvicultural data about your forest:

a) acreage in ha (1) .........

$\square$ Don't know (2)

b) type of forest: $\square$ high forest (1) $\square$ coppice (2) $\square$ mixed (3) $\square$ Don’t know (4)

c) species composition: $\square$ mainly coniferous (1) $\square$ mainly broadleaved (2) $\square$ mixed (3) $\square$ Don't know (4)

4. Did you buy or sell forests during the last 10 years?

a) Purchases:

$\square$ No (1)

$\square$ Yes (2) (please specify size in ha)

b) Sales:

$\square$ No (1)

$\square$ Yes (2) (please specify size in ha)

5. Is your forest consolidated or fragmented?

$\square$ Consolidated (1)

$\square$ Fragmented (2); number of parcels (3): average size of individual parcel (4):

6. Are you ready to cooperate with other forest owners in the following activities:

a) Sharing harvesting equipment:

$\square$ Very much (1) $\square$ Much (2) $\square$ Don’t know (3) $\square$ A little bit (4) $\square$ Not at all (5)

b) Sharing costs for making forest management plans:

$\square$ Very much (1) $\square$ Much (2) $\square$ Don’t know (3) $\square$ A little bit (4) $\square$ No at all (5)

c) Selling forest products:

$\square$ Very much (1) $\square$ Much (2) $\square$ Don’t know (3) $\square$ A little bit (4) $\square$ No at all (5)

d) Forest training:

$\square$ Very much (1) $\square$ Much (2) $\square$ Don't know (3) $\square$ A little bit (4) $\square$ No at all (5)

e) Forest road construction and maintenance:

$\square$ Very much (1) $\square$ Much (2) $\square$ Don't know (3) $\square$ A little bit (4) $\square$ No at all (5)

f) Others (please specify)

$\square$ Very much (1) $\square$ Much (2) $\square$ Don’t know (3) $\square$ A little bit (4) $\square$ No at all 